Article

\title{
To Dwell in Grace: Physical and Spiritual Situatedness in Marilynne Robinson's Lila
}

\section{Kathryn Ludwig}

English Department, Ball State University, Muncie, IN 47306, USA; kludwig@bsu.edu; Tel.: +1-765-285-8580

Received: 20 August 2019; Accepted: 9 October 2019; Published: 16 October 2019

\begin{abstract}
This article explores Marilynne Robinson's use of space in her 2014 novel Lila to illustrate a dynamic relationship between the religious and the secular. The titular character's movement among a variety of physical spaces raises questions about the possibility of "dwelling" in the sense of belonging to a place or community. Characters' earthly situatedness points to larger questions of spiritual situatedness and identity. Robinson's novel is posited as a valuable point of reference for postsecular studies, a critical perspective through which the role of the religious in literary studies is being redefined.
\end{abstract}

Keywords: religion; literature; postsecular; liminality; space; dwelling

\section{Introduction}

Marilynne Robinson's 2014 novel, Lila, seems to narrate the deliverance of its title character from physical and spiritual destitution. First, Lila is saved by a woman named Doll, who takes her out of a hostile childhood residence into a life of wandering. Later, in a reversal of the expulsion story, Lila finds her way to a garden belonging to Reverend John Ames, who becomes her husband and ushers her into grace like a foreign land. Yet, through the paradoxes of Lila's movements-Robinson figures her kidnapping as a rescue and likens Lila's home life with Ames to that of a wild bird trapped in a house- the novel overturns assumptions about what it means to dwell in grace. The narrative present is pervaded by memory as Lila confronts the troubling idea that heaven is a space from which some will be excluded-including Lila's mother figure, Doll, who "probably didn't know she had an immortal soul" (Robinson 2014, p. 21). This reality prevents Lila from fully embracing her place in Ames' life or a future in heaven. As a result, Lila maintains what Paula Geyh (Geyh 1993) describes as "transient subjectivity" in her home life with Ames, and her participation in rituals of conversion and inclusion remain unfinished or ongoing.

The novel does not set out to remedy Lila's incomplete assimilation; neither does it present Lila as an example of "weak religion" (Vattimo and Rorty 1994). Instead, hope is embodied in the suggestion that containment and exclusion are not complete. The narrative draws attention to categories of "inside" and "outside" through physical spaces such as house and town or field and forest, and through social structures such as church and marriage on the one hand and the company of godless "tramps" with whom Lila and Doll wander on the other hand. It then identifies forces that permeate, tangible forces like "dusters" (or wind storms) and enigmatic forces like sorrow and death. Through the weakening of physical, temporal and conceptual boundaries, Robinson's novel figures the deconstruction of a religious-secular binary. In this way, her work aligns with the chief concerns of the postsecular. However, in challenging binary constructions of the religious, Robinson does not abstract the sacred from a particular tradition. Robinson's novel intervenes in discourse on the religious in contemporary literature as it supplants narratives of fragilization and fragmentation with a faith-based acknowledgement of mystery. 


\section{On Robinson and the Postsecular}

The significance of Marilynne Robinson's contributions to contemporary discourse cannot be overstated. Her essays address political and social issues, history and the workings of the human mind. Religion is central to both her nonfiction and fiction writings. What is of greatest interest to postsecular studies is the way in which Robinson's novels reveal a nuanced understanding of the relationship between categories of religious and secular, while demonstrating deep investment with a specific religious tradition. In so doing, Robinson's fiction provides a valuable corrective to a blind spot in the discourse surrounding the postsecular, which Tracy Fessenden (Fessenden 2014) characterizes as the eclipse of particular religious histories.

The concept of the postsecular is constantly evolving. In its earliest articulations, the postsecular in literary studies was theorized as a religious turn following a perceived dry spell in literary engagements with the religious. John McClure (McClure 2007) drew attention to "plots of partial conversion" (p. 7), which he connected to existing notions of "weak religion" (Vattimo and Rorty 1994) and "religion without religion" (Derrida 1995). Many critique the periodizing tendency of early postsecular studies, recognizing how narratives of a "turn toward the religious" reinscribe a much-contested secularization thesis, in which secularization is the corollary of modernization (Fessenden 2014). Other scholars have observed a postsecular shift within literary studies as a check against the "presumptive" secularism of the discipline and a sign of a new willingness to engage with religion (Levitt 2009; Branch 2014).

The postsecular continues to mean different things to different people and, as a result, it is always necessary to clarify what is meant by the use of the term "postsecular." This article takes as its starting point a postsecular project whose signature is the destabilization of a religious-secular binary. This perspective contests polarizing views of the religious and the secular in favor of an acknowledgement that the two categories exist only in relation to each other and are very much intertwined. In this way, postsecular criticism participates in the widespread critique of binary thinking, which has manifested significantly in discourses on race and gender. ${ }^{1}$ This approach enables scholars to engage a dynamic understanding of seemingly opposed yet, in fact, mutually constitutive categories.

However, the emphasis on binary deconstruction in discussion of religion can result in interpretations of texts through theory that is untethered from any particular theology. Fessenden (2014) observes in postsecular discourse a tendency to identify "good religion" as a sort of vague spirituality, which seems "to float free of its own normative power," and "bad religion" as "purportedly constraining, undemocratic, backward forms of faith" (p. 165). This abstraction or decontextualization of the religious moves us away from lived experience and results in what Fessenden describes as the "subordination of particular histories, content and contexts to some essential sacred something" (Fessenden 2014, p. 161).

Marilynne Robinson is a professed adherent to mainline protestant Christianity, and her Gilead trilogy takes place in a community oriented to that religious tradition. Her novels also illustrate an engagement with the religious that involves the kind of tensions that postsecular scholarship, following Charles Taylor (Taylor 2007), describes as "cross pressure" (p. 556). Robinson shows these tensions to be consistent with, rather than departing from, deep investment in Christian belief. Lila unsettles clear distinctions between "religious" and "secular" through the use of space-by the figuring of inside and outside as they apply to notions of belonging and Christian identity. The main character is an unchurched drifter who is invited into membership in a small Iowa community and the religion they practice. In her attempts to inhabit a new religious identity, she is unable to embrace what McClure (2007) calls "secure dwelling" (p. 6) but neither does she yield to what Amy Hungerford (Hungerford 2010) calls "belief in meaninglessness." As Erin Penner (Penner 2018) writes, "Lila acknowledges impermanence, forcing it to yield not withdrawal, but even greater investment" (p. 292). Additionally,

1 For more on what Robert Baird calls, "The dual creation of an essentially religious sphere and an absolutely secular ground" (p. 166), see (Baird 2008). 
Lila does not jettison or endeavor to fragment scriptural authority (as is characteristic of partial faiths); instead, she finds the kind of tensions often attributed to fragilization (including spiritual doubt and a sense of the fallibility of language) to be available in scripture itself. Because she is mentored in her spiritual walk by Ames, who, like Robinson herself, cultivates uncertainty as a form of reverence (Robinson 2008a, p. 23), Lila discovers that belief requires an acknowledgement of mystery and that certainty is elusive even to the faithful.

\section{Situating Lila}

Lila begins with an expulsion story. Someone shouts, "Shut that thing up or I'll do it!" and a child is expelled from a house full of people-some of whom must be her family, although we do not know for sure (Robinson 2014, p. 3). This house is filled with drifters and there's no real membership or kinship available here. In this way, the first space that is described in the narrative counters traditional expectations about home and belonging. Lila is pictured waiting near the door, situated at the threshold between inside and outside.

A woman called Doll, whom the narration describes as "the loneliest woman in the world," later takes the child, Lila, from the house into the night. Doll wraps Lila in her shawl and as they venture into the dark with no destination, Lila is actually more "inside" than she was before. She is claimed by Doll and later remembers, "there were arms around her to let her know she was safe, and there was a whisper in her ear to let her know she shouldn't be lonely" (ibid., p. 5). This act of claiming, of bringing in (paradoxically through the act of kidnapping), is a sort of rebirth for Lila. She thinks, "she had been born a second time, the night Doll took her up from the stoop and put her shawl around her and carried her off through the rain" (ibid., p. 12). When they rest from their flight, Doll scrubs Lila and shaves her lice-ridden hair in what reads like a purification ritual. ${ }^{2}$ What follows is a brief period of tranquility in which Doll cultivates a garden in their temporary home with Lila by her side.

A few pages and several years later, following a period of vagrancy with Doll and a period without Doll in a "whorehouse" in St. Louis, Lila meets and marries the older Reverend Ames. Lila appears to be brought into the fold, so to speak. She is placed in a position to transition between spaces-to "convert"- through physical relocation and participation in rituals. Yet, there is a tacit understanding between Lila and Ames that Lila might leave anytime:

He told her once when there was a storm a bird had flown into the house. He'd never seen one like it. The wind must have carried it in from some far-off place. He opened all the doors and windows but it was so desperate to escape that for a while it couldn't find its way out. 'It left a blessing in the house,' he said. 'The wildness of it. Bringing the wind inside.'

(ibid., p. 19)

Despite the fact that Lila is baptized and renamed, there is an abiding tension between Lila's identity as a "wanderer" and the possibility of membership in a home, community and church. ${ }^{3}$

In portraying Lila as a wanderer, Robinson hearkens back to the figure of Sylvie in her first novel Housekeeping (Robinson 1980), which Paula Geyh (Geyh 1993) reads as an attempt to imagine a "transient subjectivity" against restrictions asserted by patriarchal structures. The character of Sylvie is a drifter who returns to the family home to care for her orphaned nieces. However, Sylvie is not domesticated by her residence there; instead, the identity of the house itself shifts as it is permeated by foreign materials (leaves and water from outside, unsorted materials like cans and newspapers). Geyh (1993) reads Sylvie's refusal to establish appropriate boundaries as a challenge to "the centrality of the space of the house in the construction of female subjectivity" (p. 104). Sylvie's resistance to

2 Just as images of burial pervade Robinson's second novel, Gilead, this instance of washing is the first of many in Lila as the novel interrogates the possibility of purification and redemption.

3 See Hall (2006) on the figure of the "wanderer." 
confinement "inside" physical spaces enacts a resistance to the restrictions imposed by the symbolic spaces of her community and of patriarchal structures, generally. Through parallels to the Biblical narrative of Naomi and Ruth, the novel suggests the possibility of subjectivity that is not bound to place and devotion that is dynamic — adjusting to change-yet fervent. ${ }^{4}$

Housekeeping informs a reading of Lila, not only because of its use of space, but also because it depicts what Satarupa Sinha Roy (Roy 2017) calls the "emancipatory possibilities of wandering" (p. 30). While Lila manages a longstanding residence in Gilead and embraces aspects of belonging there, she does not fully transition between cultural expectations assigned to drifters and those of "preacher's wife." After their marriage, the upkeep of Ames' home remains in the hands of the women of Ames' church, and Lila does not challenge this (despite her fondness for work). Lila often locks the doors when she is alone in the home, but it does not read as a proprietary act. Instead, she claims the opportunity of solitude to depart into memory, where she often wanders along the roads and fields of her past. She also continues to walk outside of town limits into the woods where she once squatted, an action that never fails to worry Ames, even as he strives to respect her transient nature.

Lila has had two experiences with houses: exclusion and confinement (in St. Louis), so her uneasiness in what seems to most to be an ideal home is not without reason. Lila knows that her husband prays for her to feel at home but, "She has never been at home in all the years of her life. She wouldn't know how to begin" (Robinson 2014, p. 107). Lila's tenuous presence in Ames' house points to questions of dwelling, which, according to Martin Heidegger, has to do with the ways in which we live in the world. The question of being "at home" in Heidegger's thinking is only partially tied to the issue of place. Rather, it is a matter of being at home in the world.

Heidegger's phenomenological project in Being and Time (Heidegger 1962) approaches the question of "being" through the figure of Dasein, which translates as "being there" (p. 236). Dasein is an activity rather than a thing, whose existence is entangled with the world through dwelling. The term "dwelling" suggests a deeper sense of "being-in-the-world" than that ascribed to objects. Dwelling is understood not merely as a cognitive process but as a "being-towards" (such as being-towards-death or being-towards-God). Heidegger's emphasis on human beings' relation to the world is, in part, an effort to depart from the mind-body dualism inherent in Cartesian and even Husserlian thought. In Heidegger's later works, the notion of dwelling becomes increasingly central to an understanding of Being. In Poetry, Language, Thought (Heidegger 1971) Heidegger traces the etymology of the German word for dwelling and finds links to "building" (as in erecting structures or cultivating) and "neighbor," as well as deeper implications that dwelling involves being "at peace" and "free from harm" (pp. 147-49). He says that such peace and security occurs "when we leave something in its own nature, when we return it specifically to its essence" (ibid.).

We find in Robinson's novel a similar preoccupation with place and how humans experience their being-in-the-world. Indeed, Lila seems to be something of a meditation on dwelling, as Robinson depicts a variety of modes of habitation and interrogates the connections between physical and spiritual situatedness. The homelessness of the main character is one of the novel's central tensions, and it works to unsettle the reader and expose our need to have Lila situated. Lila's persistent homelessness, despite the opportunity for physical stability, invites the reader to contemplate what it would mean for Lila to be "at peace."

Lila's arrival in Gilead is a confrontation between modes of dwelling that raises questions about inside-outside distinctions. Even while Lila is "inside" Gilead (in the sense of physically situated there), she remains symbolically a partial outsider. The reality of her difference is something which no amount of kindness and discretion from the citizens of Gilead can obscure. Sarah Churchwell (Churchwell 2014) describes Lila as "a fiercely unaccommodated soul who may never be at home." Churchwell's

4 In Ruth 1:16, Naomi is devoted to her mother-in-law following the death of her husband: "But Ruth replied, 'Don't urge me to leave you or to turn back from you. Where you go I will go, and where you stay I will stay. Your people will be my people and your God my God."' 
language here makes reference to Shakespeare's King Lear, who realizes that he has "ta-en too little care" for the "houseless poverty" of others. Lila, having been raised in "houseless poverty," becomes for the people of Gilead, a goad to the conscience. She represents a fruitful disruption of the secure dwelling of Ames and the citizens of Gilead, as they strive to accommodate her strangeness and include her in their number. Rowan Williams (Williams 2011) writes that Lila "retains the capacity to question the attitudes of those who are too much at home with themselves or their world" (p. 9). There is a parallel between the bird trapped in the house, "bringing the wind inside" (Robinson 2014, p. 19) and Lila's presence in Gilead.

Thus, Lila experiences only a partial sense of belonging in her community. While her presence is an invitation to citizens to see outside of themselves and "grasp the possibility of other narratives and discourses," it is this very awareness of difference which, while beneficial to their ethical development, precludes a feeling of kinship with Lila (Williams 2011, p. 11). Even for Ames, who deeply loves and respects Lila, the class difference between his wife and himself forces him to tread carefully. Robinson reflects, "It's not the simplest thing in the world for people to talk across, for example, dialectical differences" (Nance 2014).

While she is uncomfortable in houses and churches, Lila gravitates toward gardens, spaces which can be characterized as liminal (marking the transition between private and public spaces) or hybrid (both private, in the sense of belonging to someone, and public, which is to say, exterior). ${ }^{5}$ Lila's story is full of gardens: the novel begins by evoking the Garden of Eden through Lila's expulsion; a garden is the setting for her short happy time with Doll after the kidnap/rescue; after their separation, Lila finds comfort in creating a small garden next to the "whorehouse" where she briefly lives; she visits the garden outside Ames' home to weed and she surreptitiously plants potatoes and a few beans for herself; finally, she visits the Ames family gravesite, the "garden of Ameses," where she cultivates roses on the grave of Ames' first wife (Robinson 2014, p. 251). Lila cultivates gardens almost on impulse, and the gesture is either hopeful (suggesting that she will remain to see the fruit of her labor) or generous (as she plants something that someone else will reap). Often she is little more than a visitor in these gardens but this seems to be a measure of belonging that suits her. Unlike Ames, whose place is fixed, Lila is rootless. She has no known ancestry and her link to Gilead (Ames) is nearing the end of his life. So, while Lila enjoys a kind of dwelling through planting and cultivating, she stops short of "putting down roots" in Gilead.

\section{Permeability}

Robinson seems to draw attention to physical and symbolic spaces in order to show the boundaries between them breached. Forces that break through are not always benevolent, but the narrative suggests that if these can permeate so, too, can grace. Drawing on legends of wind storms or "dusters" that accompanied the 1930s Dust Bowl, Robinson provides an image of permeation that affects wanderers and house-dwellers alike:

Even before the worst of the dusters there was grit drifting around everywhere. They slept with damp cloths on their faces, and when they woke up they had to shake sand out of their hair and their blankets and clothes. People who lived in houses said they had begun stuffing wet rags into every crack they could find and sweeping their floors five times a day.

(ibid., p. 108)

The dust in this scene has corollaries in the emotional lives of Robinson's characters. For example, Lila observes that Reverend Ames' great faith cannot protect him from the sadness of his past, the pervasive memory of a deceased first wife and child. Similarly, Lila experiences shame as a force that permeates. Her experience of grace is like that of the Israelites whom God rescued out of slavery in

\footnotetext{
5 For more on liminality, see below.
} 
Egypt. Lila says, "So God let them suffer in Egypt. And they go on suffering afterward" (ibid., p. 131). She can no more leave behind the shame she has known all her life than the Israelites can leave behind the imprint of captivity. She thinks, "I am baptized, I am married, I am Lila Dahl, and Lila Ames. I don't know what else I should want. Except for the shame to be gone, and it ain't" (ibid., p. 94).

Lila's shame comes from things she has done, as well as things beyond her control. There is a general feeling of unworthiness that is founded in both her origins and her sins. There is also the shame associated with her identity as a transient. Once, when she hears a fellow wanderer say, "We ain't tramps," she asks Doll, "what are we, then?" Doll responds that they're "just folks" but Lila is unconvinced. She thinks, "Why this shame?" (ibid., p. 47). Lila makes a connection here and elsewhere between her own circumstances and the words of the Lord in Ezekiel, speaking to the Israelites: "Thou wast cast out in the open field" (ibid.; ref. Ez. 16: 6). Of all of the scripture that Lila reads, Ezekiel resonates with her most: "She never expected to find so many things she already knew about written down in a book" (ibid., p. 176). ${ }^{6}$ Though Ames tries to direct her to more palatable books in the Bible, Lila identifies with Ezekiel, where she finds articulated desolation and ruin that mirrors her own experience. The Lord says to the Israelites, "I will make you a ruin and a reproach among the nations around you, in the sight of all who pass by" (Ezekiel 5: 14, 12: 6, 12: 14). When Lila reads this she makes a connection to her own life: "She knew what those words meant without asking. In the sight of all that pass by" (Robinson 2014, p. 125). When this verse is placed in contact with Lila's shame about her identity as a transient, the potentially liberating movement in physical space associated with the wanderer is arrested by the judgment of others, who symbolically fix them as "a ruin and reproach" and "pass by" without offering help.

The novel incorporates a particular reference from Ezekiel, first by quoting the passage in full and later by interspersing lines of the passage in the narrative. The first lines read: "And as for thy nativity, in the day thou wast born thy navel was not cut, neither wast thou washed in water to cleanse thee... No eye pitied thee" (ibid., p. 42, ref. Ezekiel 16: 4-5). The narrative draws parallels between Israel and Lila as abandoned child, and between God and Doll as rescuers. Not only does Doll care for Lila "as if she were a child someone could want" (ibid., p. 47), she places her garment (shawl) over her and washes her, just as God says he did for Jerusalem. The remainder of the passage is applied in the novel variously to Lila, to Doll and to all those who fall outside God's grace: "but thou wast cast out in the open field, for that thy person was abhorred, in the day that thou wast born. And when I passed by thee, and saw thee weltering in thy blood, I said unto thee, Though thou art in thy blood, live (ibid., pp. 42-43, ref. Ezekiel 16: 5-6). In the context of Ezekiel, these lines serve to show the Israelites their guilt by reminding them that God saved them from destitution. What immediately follows is a reiteration of the threat of destruction, "I will make you a ruin." The intensity with which this passage resonates with Lila speaks to her fear that "souls could be lost forever because of things they did not know, or understand, or believe" (ibid., p. 21). She says, "I've been tramping around with the heathens. They're just as good as anybody, so far as I can see. They sure don't deserve no hellfire" (ibid., p. 225). The Ezekiel passage contains both threat and promise. Lila struggles to know which will prevail.

The tension is not resolved through any final triumphant declaration; rather, the text introduces the idea that a blessing was always inherent in the curse. When Lila asks Ames why God would let a child (figurative or literal) suffer in the first place, Ames refers to the thinking of Calvin, saying that the Old Testament depends on the idea "that Israel would know the meaning of grace because they had suffered" (ibid., p. 131). A similar expression of theodicy appears in Robinson's 2008 novel Home: "Weary or bitter or bewildered as we may be, God is faithful. He lets us wander, so we will know what it means to come home" (Robinson 2008b, p. 102). Though neither text unequivocally endorses the notion that God assigns guilt in order to bring redemption, the very fact of permeability-the suffering that permeates gladness-is part of the hope that exclusion is not complete. This idea shows up in

6 Similarly, Jack Boughton says in Home, "perdition is the one thing that always made sense to me" (Robinson 2008b, p. 119). 
Robinson's works through the physical permeation of homes and other spaces of belonging, through the permeation of present by past and future, as well as the gradual penetration of structures of shame and despair by forces of love and grace.

\section{Liminality}

The idea that material space helps us to figure social and spiritual situatedness is at the heart of ritual. We enact movement between sites of meaning through contact with sacred objects, places and words. In Robinson's Lila, characters' relationship to material space often points to their orientation toward an eternal home, which is to say to the question of belonging in heaven. ${ }^{7}$ For example, Ames' name is carved in stone in the Garden of Ameses, representing his belonging to a family and symbolizing the assurance of his election to heaven. By contrast, Lila no more expects to locate Doll's body for a proper earthly burial than she expects to see her resurrected in heaven. Ames and Doll seem to inhabit separate, irreconcilable spaces and, as a result, Lila is conflicted about her own conversion. Rather than transitioning between Doll's world and Ames', Lila embraces a state of sustained liminality. She is repeatedly pictured at the threshold between physical spaces and she remains "in thy blood," which Beech (2010) links to the state of the subject in the liminal stage of ritual. ${ }^{8}$ Yet, in depicting Lila as a liminal figure, a move that seems to affirm the separation of realms that inheres in rites of passage, Robinson once again draws attention to apparent boundaries in order to destabilize them.

The concept of liminality emerges from the field of anthropology, and refers to "the ritual patterns that societies commonly invoke to identify the process of transitions" (Jacobsen et al. 2018, p. 3). Rita Bode and Kristin Jacobsen explain, "Gennep considered the middle stage in a rite of passage the liminal one, the in between stage in which a known and familiar stability is left behind before the new point of reference could be fully embraced" (ibid.) The term "liminality" comes from the Latin "limen," which translates as "threshold" (Szakolczai 2009, p. 142). The liminal stage is the space in which boundaries are removed to enable passage between stages. Beyond its application to ritual, specifically, the term has been used in connection with other processes of transition such as social and cultural shifts and identity formation. Liminality is important to understanding the conditions under which boundaries of race, gender, class and religion shift or dissolve, and is particularly pertinent to discussions of marginalization.

Robinson's nods to the concept of liminality in Lila support the disruption of a religious-secular binary. In particular, Lila's sustained liminality contests the terms of ritual in which subjects must progress out of the middle stage (the liminal stage). It suggests, first, that movement among sites of meaning is an ongoing, recursive process rather than a one-time, linear event and, second, that the sites themselves are continuous with each other. Robinson's depiction of liminality at first seems to employ the Derridean notion of brisure, which refers to the hinge or break between categories (Derrida 1998, pp. 65, 69). Indeed this is how Lila, herself, interprets the physical, symbolic and temporal spaces among which she moves. However, as Lila's narrative unfolds, we see the liminal state not as the site of crossing over between mutually exclusive worlds, but rather a permeable site of becoming. Lila's incomplete passage through ritual transitions has the effect of maintaining possibilities which completion of the ritual would foreclose.

Lila is established as a liminal figure from the very beginning. On the first page of the novel, Lila is shown at the threshold of a house, afraid to move away from the door because of hostile cats under the porch and hopeful that the door will open and she might gain access to the house. Later, when Doll removes Lila from her biological family without officially incorporating her into a new

7 In his essay, “...Poetically Man Dwells...," Heidegger (1971) argues that man measures both his worth and his space on earth within which to dwell in relation to the heavenly: "The godhead is the 'measure' with which man measures out his dwelling, his stay on earth beneath the sky" (p. 114).

8 Beech (2010) writes that in the liminal stage "there is a link to death as the liminar is structurally 'dead' (and may be ritually buried/lie motionless/stained black/covered in blood)" (p. 3). 
one, Lila assumes a liminal identity, stuck somewhere between orphan and adoptee. As wanderers, Lila and Doll live on the physical and cultural fringes of society. When she marries Ames, Lila becomes something like an immigrant or refugee, residing in but not officially belonging to Gilead. Finally, when she becomes pregnant with Ames' child, she inhabits a state of expectancy, no longer alone because of the child within and not yet ushered into her new identity as mother. This last liminal state is the only one that Lila fully passes through in the novel-it is completed with the birth of her baby. The effect of Lila's sustained liminality on the narrative is a sense that the world is not neatly divided between poles of experience such as belonging and exile, past and present, religious and secular.

The form of the novel also has a number of markers of liminality. Rebecca Painter (Painter 2010) argues that Lila "narrates the transition from loud to quiet," characterizing the novel's form as moving between the "interiority of narrative style" of Gilead's epistolary form and the emphasis on dialogue of Home, in which a majority of narration takes place outside consciousness (Painter 2010, p. 114). Lila takes the reader into the main character's experience, but it is told at the remove of the third person. ${ }^{9}$ The novel is also temporally liminal. It takes place in a "pregnant pause," infused with both memory and expectation as Lila and Ames await the arrival of their child. The novel's status as prequel further complicates the narrative: even as Lila tells a story that predates the first book of the trilogy, it is experienced by readers with reference to those previously published works, especially Gilead, which parallels the time period depicted in Lila.

In Lila, Robinson figures liminality through physical, symbolic and temporal spaces in order to interrogate the parameters of such spaces. The first time Lila sees Reverend Ames is when she is standing on a threshold. She has ducked into his church for protection from the rain and stands in the doorway. From there, she watches Ames performing a baptism:

The candles surprised her. It might all have seemed so beautiful because she'd been missing a few meals. That can make things brighter somehow. Brighter and farther away. As if when you put your hand out you would touch glass. She watched him and forgot she was in the room with him and he would see her watching.

(Robinson 2014, p. 11)

Lila's sense that she is viewing the baptism through a window echoes moments in Housekeeping and Gilead when characters enter a space between seemingly separated sites of meaning. Laura Tanner (Tanner 2007) explains that windows act "as a porous boundary which both marks and dissolves the space between inside and outside, consciousness and body, self and other" (p. 235, fn. 6). Lila feels momentarily included in the ritual when she remembers and interprets Doll's rescue as a rebirth. But sadness intrudes on Lila's experience as she also remembers the words a fellow drifter once said about Doll: "She ain't your mama, I can tell" (Robinson 2014, p. 12). The words assert an apparent boundary between Lila's experience and the act of inclusion she is witnessing. As a result, the threshold of the church, at which the cleansing waters of baptism are juxtaposed with the pouring rain outside, seems to be the dividing line between the sacred and the secular. Lila's reluctance to enter the church in this scene depends on this assumption.

Yet, when Lila later decides to be baptized, the narrative overturns Lila's assumptions that the religious and the secular are relegated to separate physical spheres. Ames administers the ritual on a hill, as opposed to in the sanctuary of the church, using river water and a fishing bucket (ibid., p. 87). In this scene, the materials available in nature are not more or less miraculous than those kept in the sanctuary for the purpose of blessing. As Horton writes, the "miraculous qualities to be found in the worldly are not intrinsic to the objects in question; rather, they are the consequence of an engaged, interpretive relation between the perceiving subject and the existing object (ibid., p. 131).

9 Robinson said in an interview, "I knew the novel couldn't be in first person, and it couldn't be close third person, really. She's a very stoical character, and there are a lot of things she just wouldn't talk about, even to herself" (Nance 2014). 
Robinson's narrative depicts Lila's baptism not as an event but a process-an ongoing experience of becoming rather than a linear passage from one state to another. At first, the act is motivated by Ames' desire perhaps more than Lila's. He baptizes her with a sense of urgency, "before she could take off and lose herself in some rough life and then be lost in whatever came after it" (ibid., p. 100). Lila's attitude toward the act is quite different: "If none of it made sense to her now, that might change if she let it. If none of it meant anything, after all, no harm done" (ibid., p. 35). Compared with the scene at the threshold of the church when Ames performs a baptism, Lila's own baptism ritual is unaffecting:

Dipping his hand in that bucket, river water running up his sleeve while he blessed her with it. Bees buzzing, her catfish flopping in the weeds. He surely did look like he meant every word he said. The heavens torn asunder. A dove descending. There was no sign of all that except the look on his face and the touch of his hand.

(ibid., p. 100)

The only wonder in this passage comes from Lila's awareness of the old man's determination to do her good. Moments after her baptism, Lila tells the reverend of her sins, demonstrating her sense that she has not been transformed. But Ames says, "Lila Dahl, I just washed you in the waters of regeneration. As far as I'm concerned, you're a newborn babe" (ibid., p. 90). Lila remains uncertain of grace (God's and Ames'), always expecting that "this time might be the time that he would not forgive her" (ibid., p. 23). Later, when she understands that the people from her former life, especially Doll, will not partake of resurrection, Lila tries to undo her own baptism: "she went to the river and washed herself in the water of death and loss and whatever else was not regeneration" (ibid., p. 103). Lila's attempt to un-baptize herself suggests a degree of faith in the transformative power of the act.

Ames assures Lila that she cannot un-baptize herself-and yet he betrays doubt when he later re-baptizes Lila along with their baby, touching the water to her head three times, saying in desperation, "we have to keep you with us. Please God" (ibid., p. 257). The incident echoes a memory recounted in Gilead in which Ames and his fellow "pious children" baptized a litter of "anonymous" cats (Robinson 2004, pp. 21-22). Ames says, "For years we would wonder what from a cosmic viewpoint, we had done to them. It still seems to me to be a real question. There is a reality in blessing, which I take baptism to be, primarily. It doesn't enhance sacredness, but it acknowledges it, and there is power in that" (Robinson 2014, p. 23). When Ames impulsively re-baptizes Lila, the act "acknowledges" a blessing that is already present-a blessing that perhaps was first bestowed when Doll claimed Lila and cleansed her, and which Lila remembers as a rebirth. Lila's transcendent experience of witnessing Ames perform an infant baptism is linked to this first blessing through memory. The idea that Lila has been blessed all along disrupts any notion of transition out of a "secular" past into a "religious" present.

In the same way that Lila's baptism is represented as being ongoing, Lila's sense of being united with Ames in marriage emerges gradually. When Ames brings her to his house for the first time as his wife, Lila says that he can tell her to leave anytime. Ames responds in surprise that they are married, "For better and for worse!" Lila responds, "I spose so. We'll see about that" (ibid., p. 95). Her response is an expression of doubt that hurts Ames but it is not meant to. While Ames has been taught his whole life to pray, Lila has been taught to be skeptical. There is a hint later in the novel that something changes for Lila. She is remembering and says, "They'd had their wedding by then but she wasn't married to him yet" (ibid., p. 253). The form of the statement is significant: Lila's memory is expressed in the third person, rather than the first. The suggestion that Lila is at some later point "married to him" is expressed by negation rather than directly. The text repeatedly weakens Lila's situatedness as Ames' wife, allowing only glimpses of her identification with the role. One such glimpse comes when Lila has returned to the woods where she lived before her marriage and has an encounter with a young drifter. She seeks Ames at the church after the encounter and experiences a moment of insecurity when she doesn't find him there. In that moment, Lila longs to hear Ames claim her, as he does when he says, "This is Lila, Lila Ames, my wife" (ibid., p. 159). Significantly, Lila's connection to Ames is once 
again expressed not in his presence but in his absence and thus takes on the character of longing rather than belonging.

When Ames re-baptizes Lila, he bestows a blessing by expressing his love for her, much as he does when he claims her as his wife. Lila has similarly been claimed by Doll, and her commitment to Ames is impeded by her loyalty to Doll. Doll is an important paradox in the novel. Unlike the "beautiful" and saintly old man Ames, whom "everybody thinks is God," Doll bears a scar on her face, which evokes the mark of Cain (ibid., p. 133). And yet, Doll's great crime, stealing a child, is also the kindest thing that anyone has ever done for Lila. Lila had been cast out and Doll cared for her "as if she were a child someone could want" (ibid., p. 47). Every childhood memory of closeness and belonging that Lila has involves Doll. At times, Doll's absence is a stronger presence in Lila's consciousness than that of her husband or the child in her womb. Doll is associated with two symbols in the novel: a shawl and a knife. The shawl, which Doll wrapped around Lila when she rescued her, has been destroyed. The knife, which we know has done violence, remains: "Other people had houses and towns and names and graveyards. They had church pews. All she had was that knife. And dread and loneliness and regret. That was her dowry" (ibid., p. 241). The knife as "dowry" suggests a connection between the divisive potential of a blade and Lila's inability to trust and belong to Ames.

Lila is therefore suspended in the middle passage between stages of her life. In Gennep's formulation, ritual involves movement from a stage of separation, through a liminal middle stage and arriving finally in the stage of aggregation (Beech 2010, p. 3). But if forward movement requires separation from her past (Szakolczai 2009, p. 148), the text seems to suggest that Lila will never complete her passage. The manner in which the narrative form of Lila intertwines past, present and future shows these temporalities to be inextricable from each other. That is to say, it is impossible to extract oneself from one in order to experience the other. For example, despite her growing attachment to Ames, Lila's sense of secure dwelling with him is tempered by the reality that he will most surely precede her in death. The knowledge of the future is part of the way in which she experiences the present. Likewise, Lila's separation from Doll is impeded by Doll's presence in her memory. In Lila, the past intrudes upon the present so frequently that Doll-as-memory exerts a powerful influence over the story. Doll is resurrected (re-membered, so to speak) as Lila revisits their shared past in memory. ${ }^{10}$ In addition to this figural afterlife, Doll is brought back to life in a vision:

Lila thought once, when she was out walking, what if she saw someone ahead of her on the road and it was Doll ... She would tell her, I have married a fine old man ... And Doll would laugh and squeeze her hand-'It come out right, after all! I ain't dead and you ain't in some shack just struggling to get by! I had to leave for a time, but I'm back now, I'm resurrected!'

(Robinson 2014, p. 96)

Lila retrieves a likeness of Doll from memory and imagines a different future for her. In overlapping temporal and symbolic spaces as she does, Lila ensures the continuation of her liminal state.

For individuals and societies alike, the liminal stage of transitions is considered to be the most generative. Rita Bode explains that liminality entails uncertainty but there is also "becoming" with limitless possibilities (Jacobsen et al. 2018, p. 8). With the completion of a ritual, the subject achieves a new reality, but also forecloses other possibilities that were present during the middle stage. In the case of Lila, successful conversion would have the effect of both reinforcing binary constructions of place ("there and here"), time ("then and now") and meaning ("secular and religious") and also asserting Platonic unity through the resolution of difference. Instead, the narrative respects and sustains plurals, showing contact between disparate elements that yields fantastic results without erasing the uniqueness of each. Robinson provides an illustration of such contact when Lila remembers:

10 Ray Horton (Horton 2017) sees in Housekeeping an analogy between memory and resurrection that endows it with the "Calvinist wonder" of religious vision (p. 131). 
Doane said once that he saw a cyclone cross a river. It took the water in its path up into itself and crossed on dry ground, and it was just as white as a cloud, white as snow. Something like that would only last for a minute, but it showed you what kind of thing can happen.

(Robinson 2014, pp. 226-27, emphasis mine)

It is merely a glimpse - in fact, a secondhand memory of a glimpse- but it directs the reader toward an appreciation of mystery.

\section{Dwelling in Mystery}

In the book of Ezekiel, God gives the prophet Ezekiel a vision, which Lila reads with interest. In Ezekiel's vision, God is figured as "a stormy wind" coming out of the north, "a great cloud, with a fire infolding itself and a brightness round about it" (ibid., p. 68; ref. Ez. 1: 4). Ezekiel then sees four winged creatures with four faces each, accompanied by "the likeness of a man," glowing like fire, radiant like a rainbow (ibid.; ref. Ez. 1: 4-28). Twice Lila responds to the strangeness of this passage with the feeling that there is "something to it" (ibid., pp. 68,74). Here and elsewhere in scripture, Lila finds that there is something beyond the capacity of words to express and this is a point of contact for her. ${ }^{11}$ Lila particularly embraces the notion of "likeness." She sees herself as a likeness of a woman, with a likeness of a name, living the likeness of a life. It is as though she is as much a mystery to herself as she is to others. The inexpressibility of God is, then, no great surprise.

What troubles Lila is the idea that Doll and others might be cast out and "weltering" in their blood, as Doll is in the scene where she has "cut" a man, but that God might not take them up and tell them "live." Doll's crime is, in Lila's mind, the final barrier between her and heaven. Yet, the narrative suggests a measure of grace made available to Doll through Lila. Doll comes to Lila after a knife fight and Lila washes her (reenacting her own purification by Doll years earlier). ${ }^{12}$ The mingling of sin and grace in this scene evokes the enigmatic Christian connection between blood and cleansing. When Lila remembers, "There was just blood all over everything" (ibid., p. 136), the mystery of Christ's blood "covering" the sins of the world intrudes upon the hopelessness of the scene, even though Lila does not experience the comfort such an analogy would provide.

When Lila asks Ames about the salvation of people like Doll, he can only say that the things he believes about God's love and grace cannot be reconciled with "hell and the rest of it" (ibid., p. 99). Ames says in Gilead, "there are things I don't understand. I'm not going to force some theory on a mystery and make foolishness of it, just because that is what people who talk about it normally do" (Robinson 2004, p. 152). ${ }^{13}$ It is not until Lila witnesses Ames' desperation to keep Lila "with us" in eternity that she is able to imagine an alternative to a world in which belonging for some necessarily entails exclusion for others. The idea that paradise would be less than perfect for Ames without her makes her imagine that all souls bound for heaven might be accompanied by all those they cannot do without, "no matter what they've been up to in this life" (Robinson 2014, p. 258). As she pursues this line of thinking she arrives at the idea that "maybe just by worrying about it, [Ames' oldest friend] Boughton would sweep up China into an eternity that would surprise him out of all his wondering. God is good, the old men say. That would be the proof" (ibid.). It is a fanciful disruption of predominant Christian understandings of salvation, which has the effect of pointing the reader away from doctrinal debates toward a sense of the strangeness of God. Robinson (2012) explains: "We do not know how God acts or what he intends, toward ourselves or toward others" (p. 24).

11 Robinson (1998) writes that scripture is "evocation and portraiture first of all, meant to achieve likeness rather than precision, in the manner of art" (p. 241).

12 Lila reflects, "Doll had washed away her shame, some part of it" (Robinson 2014, p. 135).

13 Ames' proclamation hints at a phenomenological approach to religion, which emphasizes not theory but description of religious experience (phenomena). 
The idea that Lila can participate in Doll's purification, or that she can "worry" her into heaven, has less to say about what God does than it does about what we must do. The novel as a whole, and this moment in particular, has powerful implications for our understanding of responsibility to the other. The narrative repeatedly draws links between God's grace and the actions of people. Boughton takes up Ames' first baby "still in his blood" and confers grace through baptism (Robinson 2014, p. 170). Doll rescues Lila "like an angel in the wilderness" (ibid., p. 30). Ames shelters Lila and Lila washes Doll. Repeatedly, the novel shows sorrow accompanied by kindness and blessing, as if to suggest that grace is intertwined with suffering.

Robinson's novel does not attempt to resolve the tensions that accompany earthly life or religious belief. The narrative trajectory is not one of linear movement toward a happy ending, in which Lila is brought out of the cold into permanent safety and Ames enjoys a long life with his wife and child. Neither does Ames manage to explain away Lila's fears about Doll's eternal fate or erase the suffering and shame she has always known. The novel nonetheless articulates a meaningful engagement with the Christian faith. It reveals through its emphasis on space the power of grace to permeate apparent boundaries. It also demonstrates through the incorporation of scripture how "the effort to order the world through language is subject to radical unlikeness" (Hungerford 2010, p. 115), experienced as the ineffability of God.

In an essay titled, "Credo," Marilynne Robinson (Robinson 2012) describes Christ's "great narrative" as a "passage through the world [that] was understood, only after his death, to have revealed the way of God towards humankind" (p. 141). In speaking of "the way of God," does Robinson refer to the way of salvation - in that, Christ's passage through earthly life brought grace-or the ways of God (which is to say, the likeness of God) toward us? Perhaps it is both. Robinson emphasizes elements of Christ's earthly passage that can be found in the lives of many ordinary humans:

The astonishing, profoundly ordinary birth, the weariness of itinerancy, the beloved friends who disappoint bitterly and are still beloved, the humiliations of death-Jesus could know as well as anyone who has passed through life on this earth what it means to yearn for balm and healing.

(ibid.). ${ }^{14}$

Listening to Ames' congregation singing a hymn, Lila thinks, "Jesus drank from our cup and shared our baptism ... which meant he suffered and died like everybody else. And [Lila] was thinking how strange it was for them to be there singing songs to somebody who had lived and died like anybody. Doll would say, That's the way it is. They could as well be singing about Doll" (Robinson 2014, p. 222). When Lila anticipates a return to a life of wandering, she does so, seemingly, without fear of losing the shelter Ames has provided. Perhaps her attitude is owing to a new awareness that she is not alone in her itinerancy. She says: "It don't matter. We'll just wander a while. We'll be nowhere, and it will be alright. I have friends there" (p. 251).

\section{Conclusions}

In "The Problem of the Postsecular," Tracy Fessenden's (Fessenden 2014) critique of the postsecular in literary studies is twofold: (1) she sees in the postsecular a rhetoric of liberation from two extremes-secular emptiness and religious dogmatism-that is accomplished through progress in time and (2) she argues that the postsecular's emphasis on "discovery" (p. 158) results in the embrace of experiences of numinosity or wonder that are detached from any particular truth or meaning. To be sure, postsecular criticism has tended to privilege seeking forms of faith, which value innovative

14 Arpad Szakolczai (Szakolczai 2009) explores related terms for "experience" in Greek, including the term "limit" (peras), which implies passage through a limit and the term "pathos," "which evokes the passive sense of 'undergoing'-literally 'suffering' ... alluding both to the destruction of previous stability and the possibility of failure" (p. 149). 
religious attitudes and behaviors, over dwelling forms of faith, which adhere to traditional forms of religious practice. Perhaps this emphasis on newness is a natural outcropping of the urge within the discipline to rethink - to facilitate a shift in orientation with regard to the religious. However, as Fessenden makes clear, there are drawbacks to such celebration of radical newness, not least of which is the abstraction of the religious from the particular contexts in which it is experienced. How might postsecular studies recalibrate in the face of such criticisms? What, in fact, is the value of the "postsecular" as a frame for discussing the intersection of the religious and literature?

The literary works of Marilynne Robinson present the best way forward for postsecular studies, both by challenging the equation of "postsecular" with narratives of fragilization and also by offering what Fessenden describes as "a more pliant and quotidian frame for the overlapping spaces of religious insider- and outsiderhood" (p. 160). Robinson shows characters engaging with the religious in a particular historical and theological context- "dwelling," as it were, in mainline Protestant Christianity-yet she clearly demonstrates that their experience is complicated by the kinds of uncertainty and confusion that are considered hallmarks of "seeking" forms of the religious. Such narratives undermine the sense that critical engagements with the religious are the exclusive purview of those operating outside of established religion, which is to say those embracing highly individualized, "do-it-yourself spiritualities" (ibid., p. 157). Robinson shows characters living "in, with, through, and against the religious idioms available to them in culture" (qtd. in Fessenden 2014, p. 158). ${ }^{15}$ Furthermore, through the intergenerational scope of her narratives and the incorporation of scripture as a source of both instruction and confusion, Robinson's novels suggest that the complexity of religious experience she depicts is intrinsic to Christianity (and perhaps to any encounter with the divine), rather than a recent development owing to postmodern suspicion or fragilization. Robinson attends to the "inadequacy of our descriptive vocabularies" (Fessenden 2014, p. 161) without abstracting the sacred from the system of belief and practice through which she knows it.

Ultimately, the value of a postsecular project consists in modifying, rather than destroying, inherited discourse. Just as feminist and postcolonial criticisms have contributed to richer articulations of gender and race than were previously available, the postsecular as a critical vantage point should result in a more complex understanding of the category of the religious. But, as Fessenden argues, the postsecular in literary studies has thus far failed to move past a form of criticism in which "religion and the secular are presented as fixed alternatives, unassailable within their respective domains, with the region between them risky and uncharted, a Scylla and Charybdis strait to be boldly navigated by the postsecular protagonist or critic" (ibid., p. 160). What emerges from reading Robinson alongside Fessenden's critique of the postsecular is an awareness that by expanding our sense of what nuanced explorations of the relationship between religious and secular look like in literature we can better undertake the revision of the discipline that motivates us.

Moreover, such readings enable a vision of the postsecular that is, and should continue to be, in progress. Robinson's critical engagement with religion reminds us to cultivate uncertainty as a form of reverence, over and against the impulse to concretize. Those of us engaged in articulating the postsecular merely reinforce the binary we seek to challenge when we view the discipline as a contest between an ossified religious past and an equally intractable "new" definition. Postsecular discourse must be, like Heidegger's Dasien, an activity rather than a thing-a becoming that resists stasis even as it constructs for itself a provisional dwelling place. ${ }^{16}$

Funding: This research received no external funding.

Conflicts of Interest: The author declares no conflict of interest.

15 See (Orsi 1997)

16 I thank the reviewer for the idea that the postsecular itself is a provisional dwelling place and for all of his help as a reader of this article. 


\section{References}

Baird, Robert. 2008. “Late Secularism”. In Secularisms. Edited by Janet R. Jakobsen and Ann Pellegrini. Durham: Duke U P, pp. 162-77.

Beech, Nic. 2010. Liminality and the Practices of Identity Reconstruction. Human Relations 20: 1-18. [CrossRef]

Branch, Lori. 2014. The Rituals of Our Re-secularization: Literature Between Faith and Knowledge. Religion $\mathcal{E}$ Literature 46: 9-33.

Churchwell, Sarah. 2014. Marilynne Robinson's Lila: A Great Achievement in U.S. Fiction. The Guardian. November 7. Available online: http://www.theguardian.com/books/2014/nov/07/marilynne-robinson-lilagreat-achievement-contemporary-us-fictiongilead (accessed on 26 April 2019).

Derrida, Jacques. 1995. The Gift of Death. Translated by David Wills. Chicago: University of Chicago Press.

Derrida, Jacques. 1998. Of Grammatology. Baltimore: John Hopkins University Press.

Fessenden, Tracy. 2014. The Problem of the Postsecular. American Literary History 26: 154-67. [CrossRef]

Geyh, Paula A. 1993. Burning Down the House? Domestic Space and Feminine Subjectivity in Marilynne Robinson's Housekeeping. Contemporary Literature 34: 103-22. [CrossRef]

Hall, Joanne. 2006. The Wanderer Contained: Issues of 'Inside' and 'Outside' in Relation to Harold Gray's Little Orphan Annie and Marilynne Robinson's Housekeeping. Critical Survey 18: 37-50. [CrossRef]

Heidegger, Martin. 1962. Being and Time. Translated by John Macquarrie, and Edward Robinson. Oxford: Blackwell Publishers.

Heidegger, Martin. 1971. Poetry, Language, Thought. Translated by Albert Hofstadter. New York: Harper and Row. Horton, Ray. 2017. 'Rituals of the Ordinary': Marilynne Robinson's Aesthetics of Belief and Finitude. PMLA 132: 119-34. [CrossRef]

Hungerford, Amy. 2010. Postmodern Belief: American Literature and Religion Since 1960. Princeton: Princeton University Press.

Jacobsen, Kristin J., Kristin Allukian, Rickie-Ann Legleitner, and Leslie Allison, eds. 2018. Liminality, Hybridity, and American Women's Literature: Thresholds in Women's Writing. London: Palgrave. [CrossRef]

Levitt, Laura. 2009. What is Religion Anyway? Rereading the Postsecular from an American Jewish Perspective. Religion and Literature 41: 107-18.

McClure, John. 2007. Partial Faiths: Postsecular Fiction in the Age of Pynchon and Morrison. Athens: University of Georgia Press.

Nance, Kevin. 2014. Marilynne Robinson on Lila. Chicago Tribune. October 10. Available online: https://www. chicagotribune.com/entertainment/books/ct-prj-marilynne-robinson-lila-20141010-story.html (accessed on 2 August 2019).

Orsi, Robert. 1997. “Everyday Miracles: The Study of Lived Religion”. In Living Religion in America: Toward a History of Practice. Edited by David D. Hall. Princeton: Princeton University Press, pp. 3-21.

Painter, Rebecca M. 2010. Loyalty Meets Prodigality: The Reality of Grace in Marilynne Robinson's Fiction. Christianity and Literature 59: 321-40. [CrossRef]

Penner, Erin. 2018. A Response to Addie Bundren: Restoring Generosity to the Language of Civil Discourse in Marilynne Robinson's Lila. Studies in the Novel 50: 277-98. [CrossRef]

Robinson, Marilynne. 1980. Housekeeping. New York: Farrar, Straus and Giroux.

Robinson, Marilynne. 1998. The Death of Adam: Essays in Modern Thought. London: Picador.

Robinson, Marilynne. 2004. Gilead. New York: Farrar, Straus and Giroux.

Robinson, Marilynne. 2008a. Credo. Harvard Divinity Bulletin 36: 21-32.

Robinson, Marilynne. 2008b. Home. New York: Farrar, Straus and Giroux.

Robinson, Marilynne. 2012. When I Was a Child I Read Books. New York: Farrar, Straus and Giroux.

Robinson, Marilynne. 2014. Lila. New York: Farrar, Straus and Giroux.

Roy, Satarupa Sinha. 2017. Wandering to Dwell: Heidegger and the Phenomenology of Dwelling in Sebald's The Rings of Saturn. Modern Fiction Studies 63: 29-49. [CrossRef]

Szakolczai, Arpad. 2009. Liminality and Experience: Structuring transitory situations and transformative events. International Political Anthropology 2: 141-72.

Tanner, Laura E. 2007. 'Looking Back from the Grave': Sensory Perception and the Anticipation of Absence in Marilynne Robinson's Gilead. Contemporary Literature 48: 227-52. [CrossRef]

Taylor, Charles. 2007. A Secular Age. Cambridge: Belknap Press of Harvard University Press. 
Vattimo, Gianni, and Richard Rorty. 1994. The Future of Religion. New York: Columbia University Press.

Williams, Rowan. 2011. Native Speakers: Identity, Grace and Homecoming. Christianity and Literature 61: 7-18. [CrossRef] 